\title{
Book Review of Farghal's Jordan's Proverbs as a Window into Arab Popular Culture
}

\author{
William R. Naugle \\ University of Jordan (Fulbright Scholar) \\ Clarion University of Pennsylvania
}

Farghal's compilation of Jordanian proverbs does not disappoint, by permitting the reader a window through which to gaze into Jordanian culture. One is introduced to a vivid display of whimsey and wisdom that enteratins and educates. They say that When food is served, talk stops, and, equally, when reading these proverbs it is difficult to put the book down, as it is a feast for the imagination. Perhaps from intellectual curiosity or from a penchant for the morbid, one is immediately drawn to Chapter Seven, "Death and Madness Proverbs." If your folk go mad, your intellect will not help you could serve well as a mantra for many a faculty member seeking tenure, or equally well in a climate of political uncertainty. Such is the draw of each of these proverbs, that they conger images and usages heretofore unthought of by the reader, sometimes as delightful aphorisms, and sometimes as cautionary precepts.

Beyond leisurely reading, Farghal presents a tome that has great potential as a text for a wide array of academic lectures: culture, literature, linguistics, comparartive studies, Near Eastern studies, etc. One could easily imagine using this work as the basis for a course in sociolinguistics or linguistic pragmatics; in fact, one is reminded of Brown \& Levinson's (1978) seminal work, Politeness: Some universals in language usage, and how Jordan's Proverbs as a Window into Arab Popular Culture would complement it as a companion text for lectures on the conveyance of potent meaning, being couched within the face-saving speech act of a proverb. Perhaps it was the proverb that Grice (1975) had in mind when he arrived at his maxims, as proverbs, it would seem, adhere to all four tenets: quantity, quality, manner, and relevance. In any case, it is apparent that wit, wisdom, language, and culture are condensed into the efficiency of a proverb, at once both embracing and flouting Gricean apophthegms.

From an historical linguistics perspective, the present collection is reminiscent of the work of the Brothers Grimm's Kinder- und Hausmärchen (1812), as the proverbs not only cover a geographical area, but also have the potential to reference diachronic aspects of the Arabic language and its dialects. In fact, this would be, perhaps, the only criticism that one could proffer, that Farghal does not sound more profoundly the historical derivations of the proverbs. Of great interest would be the extent to which there may have been morphological and phonological changes over time that may have altered the lexical items and, therefore, the underlying or overall 
meaning of a given proverb. Though, admittedly, such a deviation would detract from the narrative and prose that Farghal offers generously and lovingly to the reader.

Analogous dicta are peppered throughout, as in the Jordanian proverb, $A$ snake beneath the hay, and the English version, A snake in the grass, which renders to the reader its immediate sense of the adage, for at least a part of its usage. There are times when the equivalent proverb has not been provided, as in, Like Sheik, like dog, and the missing counterpart, Like father, like son. The myriad English proverbial kith and kin notwithstanding, the potential for rendering the sayings into a purely American English idiom is tantalizing. By way of example, one could easily interpret A slave proposes, God disposes into the most American of idioms, Trenton makes, the world takes (referencing the manufacturing heritage of the city of Trenton, NJ). Of course, American propensity for slogans is derivative of the pithiness of proverbs: Be all that you can be ${ }^{1} A$ mind is a terrible thing to waste ${ }^{2}$ Sometimes you feel like a nut, sometimes you don ' $t ;{ }^{3}$ and, at least one that brings us full circle, I'd walk a mile for a Camel. ${ }^{4}$ Equally, this line of inquiry provides the basis for possible further historical research into cultural dispersion by means of tracing the slogans to their inevitable origin in proverbs.

Farghal's compilation of Jordanian proverbs will, no doubt, be used for an indeterminate number of years as a reference for professor and pupil alike, and the well-worn pages of the book will sit comfortably among those tomes that have withstood the test of time.

${ }^{1}$ United States Army, 1980.

${ }^{2}$ United Negro College Fund, 1972.

${ }^{3}$ Peter Paul Manufacturing Company, 1970s

${ }^{4}$ Camel Cigarettes, 1921

Endnote:

Farghal, Mohammad. (2019). Jordan's Proverbs as a Window into Arab Popular Culture. Newcastle upon Tyne:Cambridge Scholars Publishing 